\title{
The influence of weakly polar solvent chloroform on the state of water adsorbed by serum albumin
}

\author{
O.V. Nechypor, V. M. Gun'ko, V. N. Barvinchenko, V. V. Turov \\ The Institute of Surface Chemistry, NAS of Ukraine \\ 17, General Naumov Str., Kyiv, 03164, Ukraine \\ e-mail: isc-sec@i12.com
}

\begin{abstract}
The hydration shell structure of human serum albumin (HSA) and HSA adsorbed on a surface of highly disperse silica in a weakly polar solvent (chloroform) or with various addition of this solvent was studied by ${ }^{l} H$ NMR spectroscopy and layer-by-layer freezing-out of a liquid phase. The influence of chloroform can result in changes in the ratio of volumes of internal regions of protein globule characterized by different hydration levels and filled up with structured water unfrozen at $T<273$.
\end{abstract}

Key words: human serum albumin, highly disperse silica, chloroform, ${ }^{\prime} H$ NMR spectroscopy

Introduction Human serum albumin (HSA) is one of the main and the most studied blood plasma proteins [1-5]. In aqueous environment the albumin molecules are of deformed spheroid shape, the size of which depends on $\mathrm{pH}$ value. Cavities in globules are filled with water [6]. Being close to the surface of a protein molecule, almost all the water inside the globule is subject to the influence of polypeptide groups and amino acid residues [6]; therefore, it is bound water, which is proven by the decrease of freezing temperature. Water may be in either hydrophobic or hydrophilic environment in the cavities of a protein molecule [7]. HSA hydration occurs due to the formation of hydrogen bindings of water molecule to polar functional protein groups and Van der Waals forces,

(C).V. NECHYPOR, V. M. GUN'KO, V. N. BARVINCHENKO, V. V. TUROV, 2006 responsible for hydrophobic interactions while contacting non-polar groups. The issues of both hydrophobic and hydrophilic hydration of proteins are presented in the literature [8-11]. The influence of hydrophobic fragments on bound water may be revealed in specific properties of the system. Thus, the curve of albumin solution density dependence on its concentration in the range of small protein content shows a density minimum which is thought to be connected with the hydrophobic effect [12].

Recent studies of protein macromolecules interaction with components of aqueous-organic mixtures have attracted significant attention due to intensive development of a new scientific trend i.e. fermentative catalysis in organic environments at low water content [13]. Water has been determined to play a key role in the formation of proteins structure and their 
functioning both in aqueous [14] and low-water organic environment $[13,15,16]$. The study on mechanisms of protein-water interaction in organic environment may stimulate the creation of novel effective biocatalytic systems.

Weakly polar organic solvents may be expected to have strong effect on HSA hydration [17, 18]. Protein drying results in slight changes in its conformation [19] in comparison with the native state; however, the addition of weakly polar molecules may cause the change in the ratio of volumes of internal regions of protein globule hydrated by both hydrophobic and hydrophilic mechanisms [7-9].

Placing of proteins into the environment with the organic solvent results in the formation of heterogeneous systems which are hard to be investigated using optical methods; therefore, it is reasonable to study such HSA systems by calorimetric methods [16, 20], FTIR [16] and ${ }^{1} \mathrm{H}$ NMR spectroscopy.

Current work presents the study on hydration shell structure of human serum albumin and albumin adsorbed on a surface of highly disperse silica in a weakly polar solvent (chloroform) or on various addition of this solvent.

Materials and Methods Dry HSA (Biopharma, Ukraine) with over $95 \%$ content of monomer form was used in the work. Deuterated chloroform $\left(\mathrm{CDCl}_{3}\right)$ contained $99.9 \%$ of deuterium isotope. The samples were prepared adding a fixed portion of distilled water (5-10 $\mathrm{mg})$ to HSA powder $(70-100 \mathrm{mg})$ at intense stirring for $30 \mathrm{~min}$ at room temperature (on subsequent addition of 10-300 $\mathrm{mg}$ of deuterated organic solvent on the NMR measurements). On obtaining the equilibrium (15 min) the sample was placed in the NMR spectrometer. Deuterated chloroform was used for the signal of organic addition protons not to change the signal intensity of bound water protons.

Highly disperse silica (HDS) A-300 (Experimental plant at the Institute of Surface Chemistry, NAS of Ukraine) at the specific surface area $\mathrm{S}=300 \mathrm{~m}^{2} / \mathrm{g}$ was used. $2 \mathrm{~g}$ of HDS were added to $200 \mathrm{ml}$ of $0.5 \% \mathrm{HSA}$ solution. The adsorption was carried out for $2 \mathrm{hr}$ at constant stirring with subsequent centrifugation at $8000 \mathrm{rpm}$ for $20 \mathrm{~min}$ at $20 \pm 1^{\circ} \mathrm{C}$. To remove free protein the precipitate was washed with distilled water until absorption band of the protein in the electronic spectra disappeared. The suspension was centrifuged again and obtained residue was dried at room temperature. The amount of adsorbed albumin was calculated by the difference of initial and equilibrated HSA concentrations in the solution after contacting HDS. Protein concentration in both initial and equilibrated solutions was calculated using the corresponding spectral data (absorption at $\lambda=280 \mathrm{~nm}$ which is HSA characteristic band) obtained with a Specord M-40 (Karl Zeiss, Germany) spectrophotometer. Silica samples were obtained with the content of $60 \mathrm{mg}$ protein per $1 \mathrm{~g}$ of HDS and studied in different media (different ratio of air, water and chloroform).

NMR spectra were registered using a Bruker WP-100 SY spectrometer. The probing $90^{\circ}$ pulses were used to obtain ${ }^{1} \mathrm{H}$ NMR spectra. The temperature of the sensor was regulated with Bruker VT-1000 thermoadapter. The reproducibility of ${ }^{1} \mathrm{H}$ NMR signal intensity was $\pm 10 \%$ for $\pm 1 \mathrm{~K}$. The spectra of unfrozen water were measured after cooling the sample to 190-200 K [21-25]. The signal of water in ice (as well as macromolecule protons) did not contribute to the signal registered by the ${ }^{1} \mathrm{H}$ NMR method due to short time $\left(\sim 10^{-6} \mathrm{sec}\right)$ of proton transverse relaxation in solids.

The measurements were performed using standard NMR ampoules (5 mm diameter), containing 70-300 $\mathrm{mg}$ of the substance. The value of chemical shifts of proton resonance of bound water was determined relative to the signal of $\mathrm{CHCl}_{3}$ protons at $\delta_{\mathrm{H}}=7.26$ ppm. Measured temperature dependences of integral signal intensities $(I)$ of unfrozen water were used to calculate the dependence of unfrozen water concentration $\left(\mathrm{C}_{u w}\right)$ on temperature $(T)$, transformed into the dependence of changes in Gibbs free energy $(\Delta \mathrm{G})$ of water (as a result of its interaction with protein and silica) on $\mathrm{C}_{u w}$. Since the equilibrium of free energies of adsorbed water and ice is the prerequisite of water freezing on interphase protein/water boundary [26], the decrease of freezing temperature $(273-T)$ of adsorbed water determines the decrease of water free energy, caused by adsorption interactions $\left(\Delta \mathrm{G}=\mathrm{G}_{0}-\mathrm{G}\right.$, where $\mathrm{G}_{0}-$ free energy of ice at $T=273$ $\mathrm{K})$ [5]. As free energy of ice changes with temperature 
decrease according to the linear law, the $\Delta \mathrm{G}$ value may be calculated by the formula [26]

$$
\Delta \mathrm{G}=0.036(273-\mathrm{T})
$$

The area under the $\Delta \mathrm{G}\left(\mathrm{C}_{u w}\right)$ curve determines the value of interfacial energy $\left(\gamma_{\mathrm{s}}\right)$ of the investigated sample in aqueous environment:

$$
\gamma_{S}=K \int_{0}^{C_{u v}^{\max }} \Delta G d C_{u w}
$$

In this equation $\mathrm{C}_{u w}{ }^{\max }$ is the quantity of water unfrozen at $\mathrm{T} \rightarrow 273 \mathrm{~K}$; $\mathrm{K}$ is a constant depending on the type of units used [23]. The parameters of strongly and weakly bound water (concentration, Gibbs free energy, and interphase energy) were calculated relative to $\Delta \mathrm{G}\left(\mathrm{C}_{u w}\right)$ dependences. Weakly bound water is thought to be a part of unfrozen water, free energy of which is only slightly decreased due to intermolecular interactions with solid surface and adsorbed organic molecules. It freezes at about $273 \mathrm{~K}$. Strongly bound water may be unfrozen even at significant cooling of the system. Its free energy is greatly decreased after interaction with protein and silica $[22,23]$.

The content of each water type $\left(\mathrm{C}_{u w}{ }^{s}\right.$ and $\mathrm{C}_{u w}{ }^{w}$ for strongly and weakly bound water, respectively) and maximum values of decreasing free energy for these types of water $\left(\Delta \mathrm{G}_{s}\right.$ and $\left.\Delta \mathrm{G}_{w}\right)$ may be obtained using linear extrapolation of linear portions of the $\Delta \mathrm{G}\left(\mathrm{C}_{u w}\right)$ graphs to axes. It is noteworthy that there are two types of water, namely, unfrozen fraction $\left(\mathrm{C}_{u w}\right)$ and total amount $\left(\mathrm{C}_{\mathrm{H}_{2} \mathrm{O}}\right)$. A part of unfrozen water with $\Delta \mathrm{G}<-0.8$ $\mathrm{kJ} / \mathrm{mol}$ may be related to weakly bound water [21-25].

In narrower pores water freezes at lower temperatures which is illustrated by Gibbs-Thompson equation [27]:

$$
\Delta T_{m}=T_{m}(R)-T_{m, \infty}=\frac{2 \sigma_{s l} T_{m \infty}}{\Delta H_{f} \rho R},
$$

where $T_{m}(R)$ is melting temperature of ice localized in pores of $\mathrm{R}$ radius; $\mathrm{T}_{\mathrm{m}, \infty}-$ melting temperature of bulk ice; $\rho$ - the density of solid phase; $\sigma_{\mathrm{si}}-$ the energy of solid-liquid interaction; $\Delta \mathrm{H}_{f}-$ bulk enthalpy of fusion. This equation may be used to calculate pore size distribution according to temperature dependence of $\mathrm{C}_{u w}$ value obtained using ${ }^{1} \mathrm{H}$ NMR spectroscopy and layer-by-layer freezing-out of water for aqueous suspensions of solids or hydrated biological objects [28], when the usage of other methods of porous structure analysis is complicated.

Results and Discussion Fig. 1 presents spectra of ${ }^{1} \mathrm{H}$ NMR water bound to HSA at different deuterochloroform content in the range of $0-46 \%$ masses at various temperatures. Water concentration was $193 \mathrm{mg} / \mathrm{g}$ for all samples. Chloroform being absent, spectra have the shape of a singlet whose width increases from 1 to $20 \mathrm{kHz}$ with temperature decrease, while the degree of chemical shift in the point of maximum intensity is close to $5 \mathrm{ppm}$ (signal 1 ), which coincides with the chemical shift of bulk water [26]. Larger signal width of adsorbed water is conditioned by low molecular mobility of water bound to HSA molecules [29]. A narrower signal with the chemical shift $\delta_{\mathrm{H}}=1.3 \mathrm{ppm}$ (signal 2) is revealed on the background of a wide signal on the addition of chloroform. Its intensity increases with increasing chloroform concentration $\left(\mathrm{C}_{\mathrm{CDCl}_{3}}\right)$. Intensity of signal 2 remains steady with lowering temperature.

While $\mathrm{C}_{\mathrm{CDCl}_{3}}$ value is sufficient for chloroform isolation into a separate phase (Fig. 2) (80\% masses in suspension), signal 1 intensity at $\mathrm{T}<275 \mathrm{~K}$ becomes considerably lower than that of the same temperature in samples with less chloroform content (Fig. 1), and the intensity of signals 1 and 2 is close. Spectrum characteristics of signal 2 depend on temperature slightly. Data in Fig. 2 show signal 2 even in case of freezing the main part of liquid chloroform.

The magnitude of water chemical shift is defined by two main factors, namely, the strength of hydrogen bonds and the average number of hydrogen bonds per water molecule $[30,31]$. Calculations reveal the strength of hydrogen bonds to depend slightly on the number of water molecules [25]. Water molecules which do not participate in the formation of hydrogen-bound complexes have a chemical shift of $\delta_{0}$ $=1.3-1.7 \mathrm{ppm}$ [26]. This value is characteristic of water dissolved in chloroform, benzene, and other weakly polar solvents [32]. Chemical shift of proton resonance for ice is $\delta_{2}=7 \mathrm{ppm}$ when all water molecules have four hydrogen bonds each [33]. Therefore, data in Fig. 1, 2 may be interpreted as follows: signal 1 relates to water in the composition of 

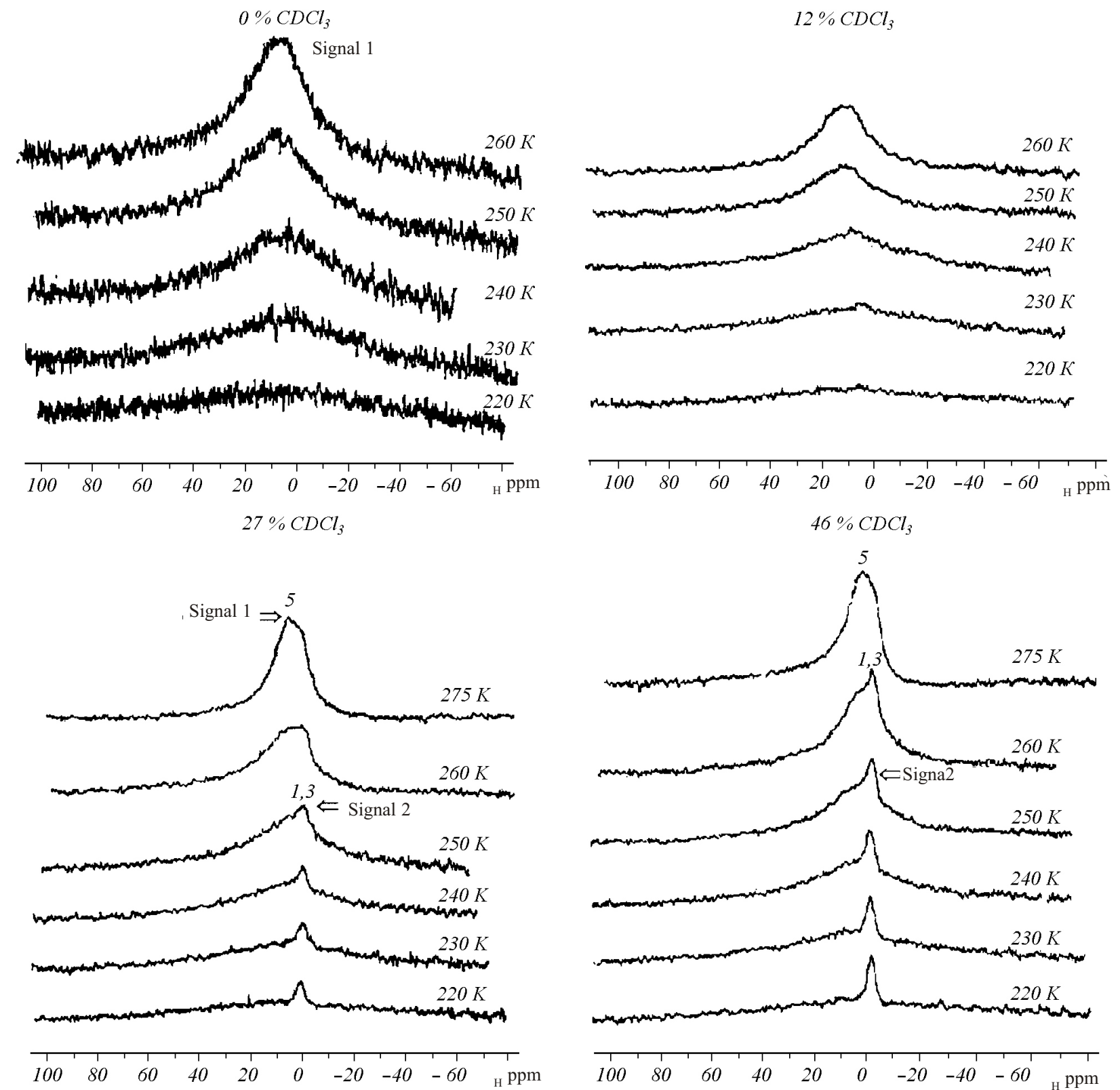

Fig.1. Effect of chloroform addition on the form of ' $\mathrm{H}$ NMR spectra of water, bound with albumin $\left(\mathrm{C}_{\mathrm{H}_{2} \mathrm{O}}=193 \mathrm{mg} / \mathrm{g}\right)$

polyassociates with the network of hydrogen bonds, which is similar to that of bulk water, and signal 2 corresponds to water molecules in weakly associated state. Previously weakly associated forms of water at the interfaces of hydrated solids and hydrophobic environment were registered for Aerosil mixtures with methylaerosil [34] and trimethylsilylated Aerosil in which the degree of substituted hydroxyl groups for trimethylsilyl ones did not exceed 50\% [35].
Fig. 3 shows temperature dependences of unfrozen water concentration $(a)$ and calculated dependences $\Delta \mathrm{G}\left(\mathrm{C}_{u w}\right)(c)$ for hydrated HSA with $0-80 \%$ chloroform masses content. Vertical fragments of the graphs linked to unfrozen water at $\mathrm{T}>250 \mathrm{~K}$ relate to HSA powders in the range of $\Delta \mathrm{G}<-1 \mathrm{~kJ} / \mathrm{mol}$ on $\Delta \mathrm{G}\left(\mathrm{C}_{u w}\right)$ dependences. According to abovementioned criteria of strongly and weakly bound water, hydrated HSA contains only strongly bound water. Chloroform 


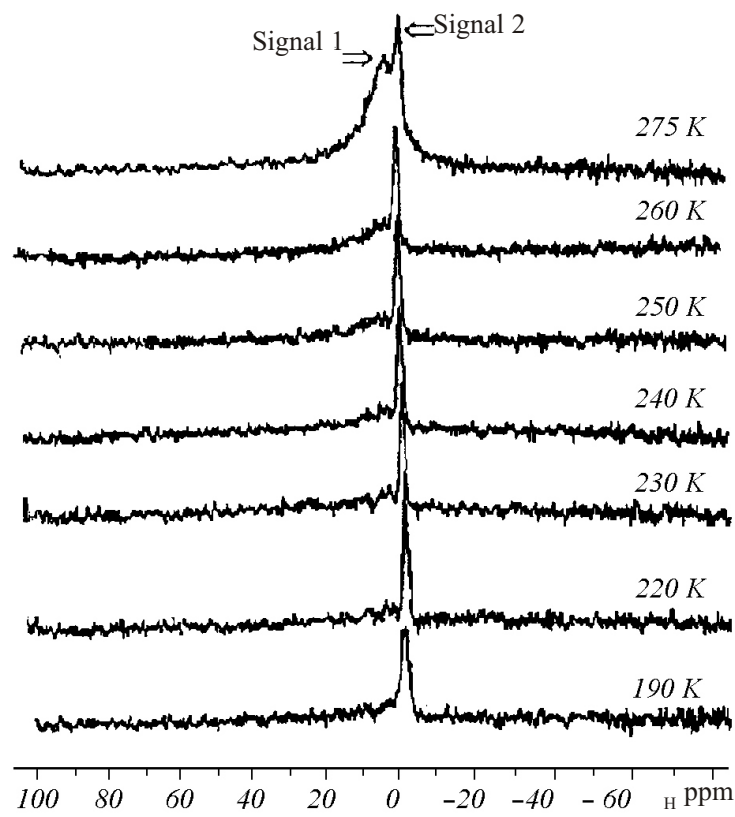

Fig.2. Temperature changes in ${ }^{1} \mathrm{H}$ NMR spectra of water $\left(\mathrm{C}_{\mathrm{H}_{2} \mathrm{O}}\right.$ $=193 \mathrm{mg} / \mathrm{g}$ ) adsorbed on HSA at $\mathrm{C}_{\mathrm{CDCl}_{3}}=80 \mathrm{wt} \%$.

environment reveals sharp decrease in bound water concentration at $\mathrm{T}>220 \mathrm{~K}$ and transformation of some water from the strongly bound state into weakly bound one (freezing at about $273 \mathrm{~K}$ ). Fig. 3, b, $c$ shows analogous results for HSA adsorbed on HDS A-300 surface. The transfer of some strongly bound water into weakly bound state in chloroform environment is not seen.

Weakly associated water of hydrated HSA molecules is supposed to be in structural cavities restricted by hydrophobic groups. Due to structural restrictions or peculiarities of intermolecular interactions in these cavities, water molecules have thermodynamic advantage while existing in a weakly associated state.

It is noteworthy that chemical shift of weakly associated water coincides with that of water dissolved in chloroform [25]. However, water solubility in chloroform does not exceed $0.6 \%$ at room temperature, and it decreases with decreasing temperature. The concentration of weakly associated water in the system albumin/water/chloroform in Fig. 2 is $1.7 \%$ which is much higher than the maximum concentration of dissolved water in chloroform at $\mathrm{T}=$ $190 \mathrm{~K}$ [35]. Taking into account that the main part of chloroform freezes at this temperature, the conclusion is made that weakly bound water concentration in chloroform unfrozen due to the interaction with HSA molecules would equal several dozens percent.

Having been freeze-dried, the majority of HSA molecules retain their native globular structure in which air borders mainly hydrophilic sites easily adsorbing water and forming hydrate shell of protein molecules in both air and aqueous environment [7]. While adding chloroform, its molecules are mainly concentrated on hydrophobic sites of the protein, not bound to water (or in hydrophobic cavities). Both hydrophobic and hydrophilic constituents of powders are spatially divided and to some extent chloroform presence has insignificant effect on hydrate features of protein molecules. Stepwise change of water characteristics bound to HSA at the change in chloroform concentration (Fig. 3, a, c) may be conditioned by such a change in native conformation of protein molecules which provides minimum of free energy of the system on transferring from air to weakly polar $\mathrm{CDCl}_{3}$ environment. In this case hydrophobic areas of HSA molecules become more accessible for chloroform, while hydrophilic centres change their spatial location to provide their minimum free energy in nonpolar environment. This process is accompanied by total decrease in HSA molecules hydration (Fig. 3, a, c) and, probably, by the formation of additional intramolecular hydrogen bonds between functional HSA groups. HSA adsorbed on HDS surface (Fig. 3, b, c) does not have the same effect which is probably conditioned by weak conformational flexibility of adsorbed albumin.

According to the data of Fig. 2 there is only signal 2 at $\mathrm{T}<240 \mathrm{~K}$ in ${ }^{1} \mathrm{H}$ NMR spectra for HSA suspension in $\mathrm{CDCl}_{3}$. Bound water concentration, responsible for this signal, is $80 \mathrm{mg} / \mathrm{g}$ (Fig. 3, a). Since chloroform molecules are capable of solvating hydrophobic groups of HSA molecules, hydrophobic cavities of HSA molecules contain both water and chloroform molecules. Taking into account a large amount of weakly associated water, water and chloroform inside hydrophobic areas of protein globule are expected to be capable of forming concentrated solution of water in chloroform i.e. the properties of water participating in hydrophobic hydration are considerably different 


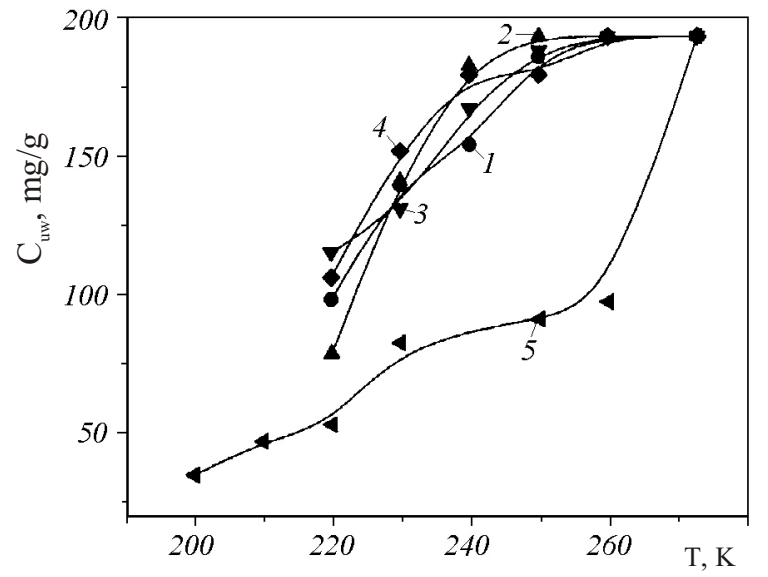

a

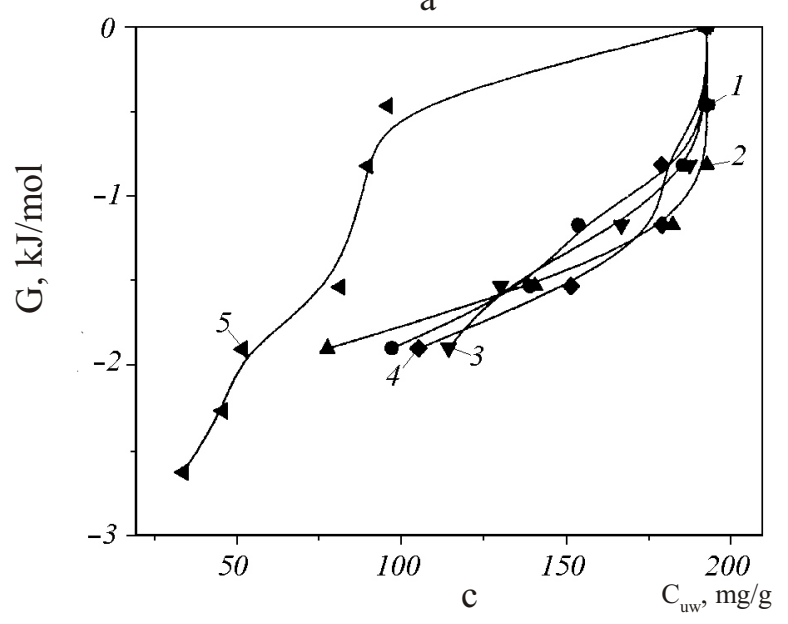

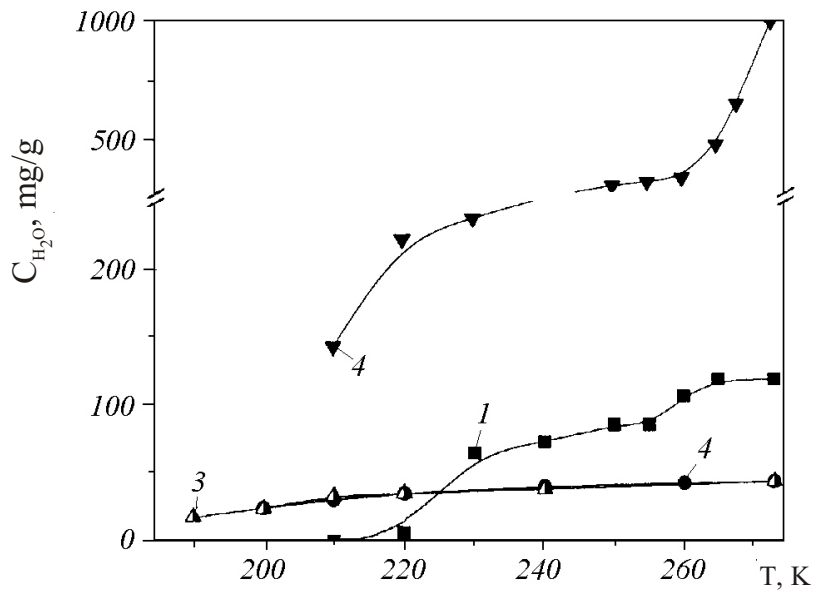

b

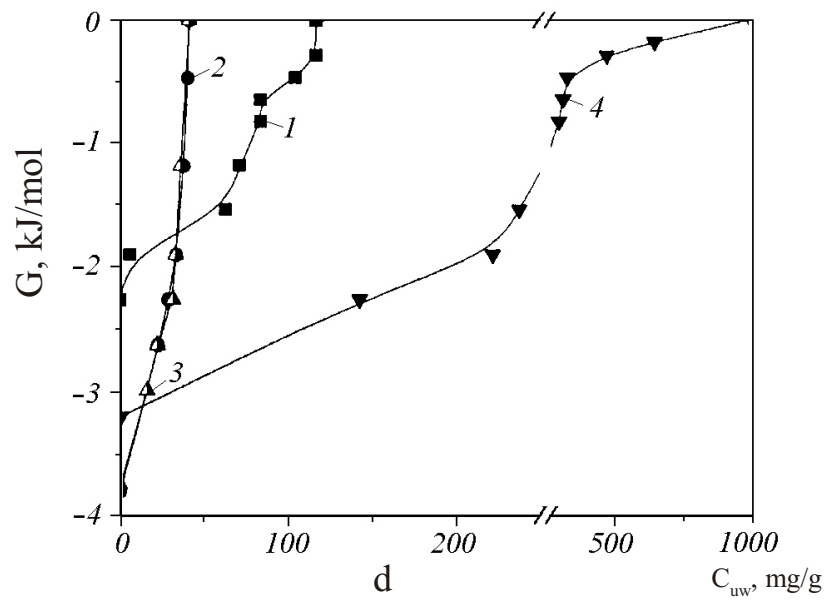

Fig.3. Temperature dependences of unfrozen water concentration and dependence of Gibbs free energy on unfrozen water concentration in the system $\mathrm{HSA} /$ water/chloroform $\left(a, c: 1-0 \% \mathrm{CDCl}_{3}, 2-12 \% \mathrm{CDCl}_{3} ; 3-27 \% \mathrm{CDCl}_{3} ; 4-46 \% \mathrm{CDCl}_{3} ; 5-80 \% \mathrm{CDCl}_{3}\right)$ and (HSA-HDS)/water/chloroform (b, $d$ : 1 $117.67 \mathrm{mg} / \mathrm{g}$ in $\mathrm{CDCl}_{3} ; 2-41.9 \mathrm{mg} / \mathrm{g}$ in $\mathrm{CDCl}_{3} ; 3-41.9 \mathrm{mg} / \mathrm{g}$ in air; 4 - in water $)\left(\mathrm{C}_{\text {н2о }}=193 \mathrm{mg} / \mathrm{g}\right)$ at $\mathrm{CDCl}_{3}$ content $0-80 \mathrm{wt} . \%$.

from the properties of volume water, structured by the network of hydrogen bonds.

Table presents characteristics of bound water layers (concentration, Gibbs free energy, value of interfacial energy) and chloroform concentration for all the systems studied. For hydrated albumin with added $\mathrm{CDCl}_{3}$ the value of interfacial energy is slightly dependent on $\mathrm{CDCl}_{3}$ concentration until complete chloroform environment is formed, then it decreases sharply due to the transformation of a portion of strongly bound water into weakly bound state. In case if albumin is adsorbed on silica surface, interfacial energies in air and chloroform environment coincide. Weakly bound water is not registered in chloroform environment even in case if $\mathrm{C}_{\mathrm{H}_{2} \mathrm{O}}$ increases two-fold.
Fig. 4 presents distribution of unfrozen water concentration (internal cavities filled up with unfrozen water) according to pores radius $\left(\mathrm{PSD}_{u w}\right.$ ) for hydrate $\mathrm{HSA}$ in the presence of $\mathrm{CDCl}_{3}$. Two maxima are registered in initial HSA on $\mathrm{PSD}_{u w}(\mathrm{r})$ dependence. The first maximum corresponds to pore radius $r=0.35$ $\mathrm{nm}$, the second maximum is $r=1 \mathrm{~nm}$. The former increases with chloroform concentration growth and shifts toward high $r$ values. Stepwise change of distribution curve shape occurs in chloroform environment. Maximum intensity at $r=0.35 \mathrm{~nm}$ decreases several times and new maxima appear at $r=$ 0.8 and $8 \mathrm{~nm}$. In case if hydrated albumin is in initial state or at relatively small chloroform additives, the main part of water is likely to be concentrated in microcavities with the radius $r=0.35 \mathrm{~nm}$, formed by 


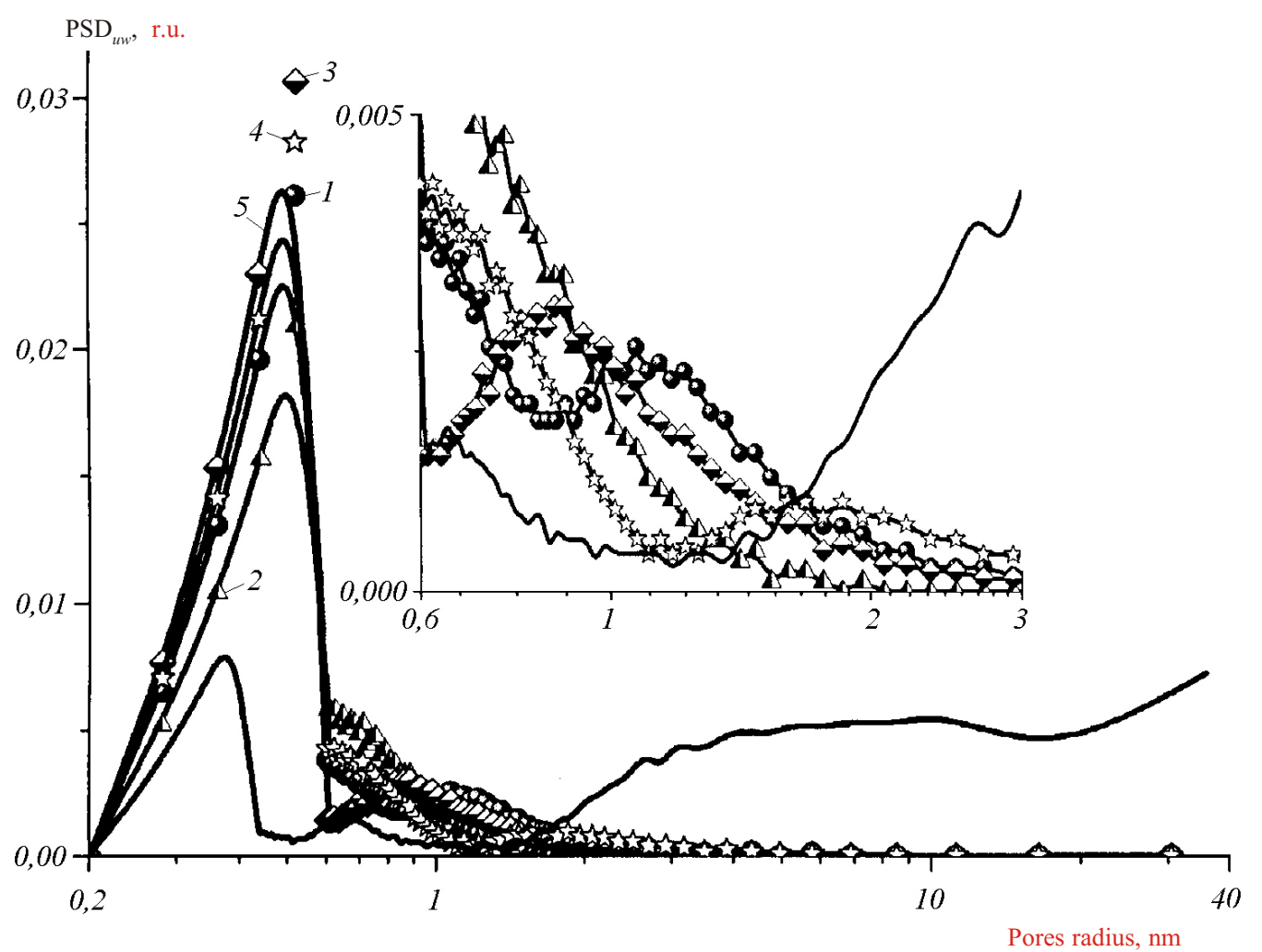

Fig.4. Dependence of distribution by sizes of cavities, filed up with not freezing water on chloroform content in hydrate powders of HSA and its suspensions: 1 $0 \% \mathrm{CDCl}_{3}, 2-12 \%$ $\mathrm{CDCl}_{3} ; 3-36 \% \mathrm{CDCl}_{3} ; 4$ $-72 \% \mathrm{CDCl}_{3} ; 5-80 \%$ $\mathrm{CDCl}_{3}$ ) hydrophilic sites of protein molecule, with which water molecules may form stable hydrogen bonds. The size of these cavities increases because of the effect of chloroform. It is probably caused by conformational changes in the protein molecules stabilized by growth of hydrophobic areas, where water is in weakly associated state which is revealed in ${ }^{1} \mathrm{H}$ NMR spectra in signal 2.

In case if chloroform forms continuous phase, conformation changes in the protein molecules cause water removal from narrow hydrophilic areas into bigger cavities, formed anew with smaller amount of hydrophilic centers. This water becomes weakly bound (in the current case with HSA), since its interaction with interfacial boundary decreases, but it remains strongly associated as it forms a net of hydrogen bonds with other water molecules. Some water remains in hydrophobic areas with $r=0.35 \mathrm{~nm}$, therefore, it is strongly bound (having strong perturbation influence from the surface) though weakly associated (having chemical shift $\delta_{\mathrm{H}}=1.4$ ppm). This special state of water is stabilized by weakly polar deuterochloroform environment.
Probable condition for water transfer into weakly associated state is both presence of a sufficient number of hydrophobic areas, interacting with water molecules only according to disperse mechanism, either on the surface or in the environment, and spatial restrictions, hindering from the formation of three-dimensional network of hydrogen bonds. HSA adsorption on silica surface diminishes sharply conformational flexibility of HSA molecules and internal cavity volume, where hydrophobic hydration of protein molecule is possible in weakly polar environment.

Conclusions Hydrated HSA contains only strongly associated water at chemical shift $\delta_{\mathrm{H}}=5 \mathrm{ppm}$, adsorbed according to the mechanism of hydrophilic hydration. Signals of water adsorbed by the mechanisms of hydrophobic and hydrophilic hydration are separate in ${ }^{1} \mathrm{H}$ NMR spectra in the presence of weakly polar chloroform molecules. The concentration of weakly associated water $\left(\delta_{\mathrm{H}}=1.3\right.$ $\mathrm{ppm}$ ) is much higher than maximum concentration of water dissolved in chloroform at $\mathrm{T}=190 \mathrm{~K}$. It increases with increasing chloroform concentration. 
Characteristics of bound water layers (concentration $\left(C_{\text {нг2 }}\right)$, Gibbs free energy $\left(Д G^{s}\right)$ and the value of interfacial energy (2) in hydrated albumin (HSA) and albumin, adsorbed on silica surface (HDS))

\begin{tabular}{c|c|c|c|c|c}
\hline Sample & $\mathrm{C}_{\mathrm{CDC}_{3}}, \mathrm{wt} . \%$ & $\Delta \mathrm{G}^{\mathrm{s}}, \mathrm{kJ} / \mathrm{mol}$ & $\mathrm{C}_{\mathrm{H}_{2}}, \mathrm{mg} / \mathrm{g}$ & $\mathrm{C}_{u v w}{ }^{w}, \mathrm{mg} / \mathrm{g}$ & $\gamma \mathrm{S}, \mathrm{J} / \mathrm{g}$ \\
\hline $\begin{array}{c}\text { HSA hydrated } \\
\text { powder }\end{array}$ & 0 & -2.7 & 193 & 0 & 19.6 \\
& 12 & -2.25 & 193 & 0 & 22 \\
& 27 & -3.2 & 193 & 0 & 21 \\
& 46 & -2.7 & 193 & 0 & 13 \\
HSA/HDS & 80 & -3.5 & 193 & 90 & 6 \\
& 0 & -2.25 & 42 & 0 & 7 \\
& 80 & -3.7 & 42 & 0 & 8 \\
\end{tabular}

The change in native conformation of protein globule is shown to occur under the influence of weakly polar chloroform environment which is supported by partial dehydration of surface and considerable decrease of internal cavity volume, binding water according to the mechanism of hydrophilic hydration.

Adsorptive fastening of protein molecules on silica surface decreases their conformation mobility due to which weakly associated form of water is not registered in the ${ }^{1} \mathrm{H}$ NMR spectra for system (HSA-HDS)/water/chloroform.

\section{О. В. Нечипор, В. М. Гунько, В. Н. Барвинченко, В. В. Туров}

Влияние хлороформа на состояние воды, адсорбированной сывороточным альбумином

Резюме

Методом ${ }^{\prime}$ Н ЯМР спектроскопии с вымораживанием жидкой фазы изучено строение гидратной оболочки лиофилизированного и сорбированного на поверхности высокодисперсного кремнезема сывороточного альбумина человека, находящегося в слабополярном растворителе (хлороформе) или при его добавлении к гидратированной системе. Показано, что влияние хлороформа может приводить к изменению объемов внутренних областей белковой глобулы, характеризующихся различной гидрофильностью и заполненных структурированной водой, которая не замерзает при $T<273$ K.

Ключевые слова: вода, сывороточный альбумин человека, высокодисперсный кремнезем, хлороформ, ${ }^{l}$ Н ЯМР спектроскопия.

\section{REFERENCES:}

1.Чагер С. И. Транспортная функция сывороточного альбумина.-Бухарест: Из-во Академии наук СРСР, 1975.—184 с.

2.Principles of Biochemistry / Eds A. L. Lehninger, D. L. Nelson, and M. M. Cox.-Worth, 2004.- p.

3.Liu Y., Xie M.-X., Jiang M., Wang Y.-D. Spectroscopic investigation of the interaction between human serum albumin and three organic acids // Spectrochim. Acta A.—2005.-61.-P. 2245-2251.

4.Norde $W$., Giacomelli C. E. BSA structural changes during homomolecular exchange between the adsorbed and the dissolved states // J. Biotechnol.-2000.-79.-P. 259-268.

5.Prat L. R., Pohorille A. Hydrophobic effects and modeling of biophysical aqueous solution interfaces // Chem. Rev.-2002.-102.-P. 2671-2692.

6.Кайвяряйнен А. И. Динамическое поведение белков в водной среде и их функции.-Л.: Наука, 1980.-272 с.

7.Сузи Г. Структура и стабильность биологических макромолекул / Под ред. М. В. Волькенштейна.-М.: Мир, 1973.—584 с.

8.Tiwns J. K. Moisture content in proteins: its effects and measurement // J. Chromatogr. A.-1995.-705.-P. 115-127.

9.Pouliquen D., Gallois Y. Physicochemical properties of structured water in human albumin and gamma-globulin solutions // Biochimie.-2001.-83.-P. 891-898.

10.Robinson G. W., Cho C. H. Role of hydration water in protein unfolding // Biophys. J.-1999._77.—P. 3311-3318.

11.Vogler E. A. Structure and reactivity of water at biomaterial surfaces // Adv. Coll. and Interface Sci.-1998.-74.-P.61-117.

12.Schade P., Klein H., Egry I., Adamovic X., Klii D. Hydrophobic volume effects in albumin solutions // J. Coll. and Interface Sci.-2001.-234.-P. 445-447.

13.Гладилин А. К., Левашов А. В. Стабильность ферментов в системax c органическими растворителями // Биохимия.-1998.-63.- С. 408-421.

14.Protein-solvent interaction / Ed. R. B. Gregory.-New York: Dekker, 1995.-191 p.

15.Griebenow K., Klibanov A. M. On protein denaturation in aqueous-organic mixture but not in pure organic solvents // J. Amer. Chem. Soc.-1996.-118.-P. 11695-11700. 
16.Сироткин В. А., Соломонов Б. Н., Файзуллин Д. А., Федотов В. Д. Сорбция паров воды и ацетонитрила сывороточным альбумином человека // Журн. физ. химии.-2002.-76. - С. 2255-2262.

17.Sirotkin V. A., Borisover M. D., Solomonov B. N. Heat effects and water adsorption by human serum albumin on its suspension in water-dimethyl sulfoxide mixtures // Thermochim. Acta.-1995.-256.-P. 175-183.

18.Sirotkin V. A., Borisover M. D., Solomonov B. N. Effect of chain length on interactions of aliphatic alcohols with suspended human serum albumin // Biophys. Chem.—1997.-69.-P. 239-248.

19.Фрайфелдер Д. Физическая биохимия. Применение физико-химических методов в биохимии и молекулярной биологии.-Мир, 1980.-582 с.

20.Сироткин В. А., Королев Д. В. Тепловые эффекты дегидратации сывороточного альбумина человека в различных органических растворителях // Журн. физ. химии.-2005.-79, № 2.-С. $352-358$.

21.Gun'ko V. M., Zarko V. I., Turov V. V., Leboda R., Chibowski E. Distribution effect of the second phase in disperse silica/X oxides $\left(\mathrm{X}=\mathrm{Al}_{2} \mathrm{O}_{3}, \mathrm{TiO}_{2}, \quad \mathrm{GeO}_{2}\right)$ on their surface properties // Langmuir.-1999.-15.-P. 5694-5702.

22.Turov $V$. $V$., Leboda R. Application of ${ }^{1} \mathrm{H}$ NMR spectroscopy method for determination of characteristics of thin layers of water adsorbed on the surface of dispersed and porous adsorbens // Adv. Coll. and Interface Sci.-1999.-79.-P.173-211.

23.Turov V. V., Leboda R. Chemical shifts of adsorbed molecules and free surface energy of carbon adsorbents by studied of ${ }^{1} \mathrm{H}$ NMR spectroscopy // Chemistry and physics of carbon / Ed. L. R. Radovic.-New York: Marcel Dekker, 2001.-27.-P.67-124.

24.Turov V. V., Barvinchenko $V$. N. Structurally ordered layers of water at the $\mathrm{SiO}_{2} /$ Ice interface and influence of adsorbed molecules of protein hydrolysate on them // Coll. Surface. B.-1997.-8.-P. 125-132.

25.Gun'ko V. M., Turov V. V. Structure of hydrogen bonds and ' $\mathrm{H}$ NMR spectra of water at the interface of oxides // Langmuir.-1999.-15.-P. 6405-6415.

26.Химия поверхности кремнезема / Под ред. А. А. Чуйко.-К., 2001.-Ч. 1.-736 c.
27.Kondori K., Uoya Y., Ishikawa T. Effects of acetonitrile on adsorption behavior bovine serum albumin onto synthetic calcium hydroxyapatite particles // J. Coll. and Interface Sci.-2002.-252.-P. 269-275.

28.Гунько В. М., Туранская С. П., Нечипор О. В., Юхименко Е. В., Туров В. В., Чуйко A. А. Слабо ассоциированная вода в биологических объектах и на межфазной границе кремнеземов // Химия, физика и технология поверхности.-К.: Наук. думка, 2006.-Вып. 11-12.-С. 397-430.

29.Манк В. В., Лебовка Н. И. Спектроскопия ядерного магнитного резонанса в гетерогенных системах.-Киев: Наук. думка, 1988.-202 c.

30.Pople J. Proton resonance shifts in molecules with hydrogen bonds // Proc. Roy. Soc.-1957.-239.-P. 541-550.

31.O'Reilly D. E. Temperature and pressure dependence of the proton chemical shift in water // J. Chem. Phys.-1974.-61.-P. $1592-1593$.

32.Gun 'ko V. M., Turov V. V., Skubiszewska-Zieba J., Leboda R., Tsapko M. D., Palijczuk D. Structural characteristics of a carbon adsorbent and influence of organic solvents on interfacial water // Appl. Surf. Sci.-2003.-214.-P. 178-189.

33.Kinney D. R., Chaung I.-S., Maciel G. E. Water and the silica surface as studied by variable temperature high resolution ${ }^{1} \mathrm{H}$ NMR // J. Amer. Chem Soc.-1993.-115.-P. 6786-6794.

34.Turov V. V., Mironiuk I. F. Adsorption layers of water on the surface of hydrophilic, hydrophobic and mixed silicas // Coll. and Surf. A.-1998.-134.-P. 257-263.

35.Turov V. V., Gun'ko V. M., Bogatyrev V. M., Zarko V. I., Gorbik S. P., Pakhlov E. M., Leboda R., Shulga O. V., Chuiko A. A. Structured water in partially dehydrated yeast cells and at partially hydrophobized fumed silica surface // J. Coll. Interface Sci.-2005.-283.-P. 329-343.

Надійшла до редакціi 29.03 .06 